\title{
PENDIDIKAN AGAMA ISLAM MULTIKULTURAL BERBASIS TASAWUF \\ (Kajian fenomenologis pada Senenan dan Selosoan di Pondok Pesantren Ngalah)
}

\section{Uswatun Chasanah \\ Universitas Yudharta Pasuruan}

Email : uswatunchasanah194@gmail.com

\begin{abstract}
Abstrak
Islam hadir memberikan petunjuk bagi umat manusia, karena ajarannya penuh dengan nilai dan norma yang menerangi jalan menuju kebahagiaan sejati dunia akhirat, akan tetapi nilai dan norma yang terkandung di dalamnya tidak serta merta dapat diraih tanpa proses pembelajaran yang tepat, efektif dan efisien, mempertimbangkan dimensi, hakikat dan tujuan penciptaan manusia secara keseluruhan. Fokus utama penelitian ini didasarkan pada fenomena keagamaan pada Seninan dan Selosoan yang dilaksanakanakan di Pesantren Ngalah, yaitu tentang:1) nilai-nilai islam multikultural apa saja yang diajarkan pada Seninan dan Selosoan, 2) bagaimanakah proses pembelajaran pendidikan agama Islam multikultural yang didasarkan pada nilai-nilai pendidikan pada Senenan dan Selosoan, dan 3) bagaimanakah model pendidikan agama islam multikultural yang diajarkan pada Seninan dan Selosoan dalam pengembangan sikap multikultural. Dari kajian lapangan diperoleh temuan: Pertama, nilai yang diajarkan pada Senenan dan Selosoan bersumber dari eksistensi pendidik yang diaktualisasikan secara tekstual dan kontekstual yang menghasilkan:11 nilai. Kedua proses pembelajaran dilakukan dengan dua modus. Ketiga, model pendidikan agama islam multikultural yang diajarkan pada Senenan dan Selosoan dalam mengembangkan sikap multikultural menggunakan model pendekatan transformatif transendental.
\end{abstract}

Kata kunci: Pendidikan, Agama Islam, Senenan dan Selosoan, Sikap,

Multikultural.

\section{Abstract}

Islam presents instruction for mankind, because its teachings are full of values and norms that illuminate the path to the true happiness in the hereafter, but the values and norms contained in it do not necessarily achieve without a proper, effective and efficient learning process, considering the dimensions, the nature and purpose of human creation as a whole. The main focus of this research is based on religious phenomena in the Seninan and Selosoan conducted at the Ngalah Islamic Boarding 
School, which are about: 1) the values of the multicultural Islam are taught in the Seninan and Selosoan, 2) how is the learning process of multicultural Islamic religious education based on the values of education in Seninan and Selosoan, and 3) how is the multicultural Islamic religious education model taught in Seninan and Selosoan in developing multicultural attitudes. From the field study, it was found that: First, the values taught at Senenan and Selosoan were derived from the existence of educators both are textual and contextual which produce: 11 values. Both learning processes are carried out in two modes. Third, the multicultural Islamic religious education model taught at Seninan and Selosoan in developing multicultural stance using a transcendental transformative approach model.

Keywords: Education, Islamic religion, Senenan and Selosoan, Attitude, Multicultural.

\section{PENDAHULUAN}

Pendidikan merupakan bimbingan secara sadar terhadap perkembangan jasmani dan rohani menuju terbentuknya kepribadian yang utama, oleh karenanya pendidikan menjadi wahana penting untuk pengembangan fitrah dan penanaman ilmu pengetahuan yang memiliki kegunaan pragmatis dalam kehidupan masyarakat. Senada dengan hakikat dan tujuan pendidikan Islam sebagai upaya mendidik budi pekerti dan pembentukan jiwa, yang pada akhirnya mampu mewujudkan tujuan hakikinya yaitu mencapai kesejahteraan hidup di dunia dan keselamatan hidup di akhirat. Mendidik dan memperbaiki budi pekerti manusia juga merupakan misi utama Nabi SAW sebagai utusan Allah SWT, karena budi pekerti yang baik dan benar adalah yang ditentukan oleh agama yang baik dan benar.

Adapun tugas pendidikan agama ditekankan untuk mengembangkan manusia yang beriman dan bertakwa kepada Tuhannya, upaya tersebut bisa dilakukan melalui optimalisasi peran orang tua, keluarga, lembaga pendidikan, masyarakat dan pemerintah sebagai lingkungan pendidikan. Ketiganya berperan dalam meletakkan pondasi agama, pengetahuan dan ketrampilan dasar, nilai moral dan sosial serta pandangan hidup dan berperan aktif dalam keluarga dan masyarakat. Sebagaimana Maslikhah menambahkan, bahwa pendidikan islam menempati posisi unggul dalam Sistem Pendidikan Nasional. Peran strategis pendidikan agama Islam dalam Sistem Pendidikan Nasional terletak pada fungsi pentingnya dalam mencapai tujuan nasional, lebih utamanya dalam mengembangkan manusia yang beriman dan bertakwa kepada Tuhan YME dan berbudi pekerti luhur sebagai bagian esensial dalam pembangunan manusia seutuhnya. 
Sedangkan Seninan dan Selosoan dalam penelitian ini adalah kegiatan keagamaan yang dilaksanakan pada hari Senin malam dan Selasa siang di Pesantren Ngalah yang berisi pengamalan ibadah ritual berjamaah, berbagai macam salat sunat, praktik zikir, doa, tausiyah yang merupakan kegiatan rutin dalam implementasi tasawuf khususnya praktik dan pengembangan Tasawuf yang diikuti oleh anak-anak, remaja, orang dewasa, manula dan sebagaian santri senior atau mahasiswa/wi dan jumlah pengikutnya mencapai ratusan orangsebagai upaya pengenalan, implementasi, dan pengembangan tasawuf dalam Tārekat Naqsyabandiyah Khalidiyah di Pesantren Ngalah.

\section{METODE PENELITIAN}

Penelitian ini menggunakan pendekatan kualitatif bertujuan untuk mendeskripsikan, memahami, dan menginterpretasi fenomena-fenomena, peristiwa, aktivitas sosial yang terjadi di pesantren Ngalah Pasuruan. Jenis studi kasus dipilih dalam penelitian ini, karena penelitian dilakukan terhadap suatu kesatuan sistem dalam bentuk program, aktivitas, peristiwaperistiwa atau sekelompok

Data dikumpulkan dengan tiga prosedur yaitu: 1) wawancara mendalam (indepth interview); terhadap informan kunci yang barkaitan dengan Nilai karakter InklusifPluralis dan strategi pembentukannya 2) observasi partisipan; terhadap aktivitas dan peristiwa yang ada dalam hubungannya dengan pembentukan karakter inklusif-pluralis dan 3) studi dokumentasi (studi dokumen).

Teknik analisis data menggunakan teknik analisis model interaktif dengan menempuh tiga langkah yang terjadi secara bersamaan yaitu: 1) reduksi data, yaitu menggolongkan data tentang nilai karakter inklusifpluralis dan strategi pembentukannya membuang data yang tidak ada kaitannya dengan focus penelitian; 2) penyajian data, yaitu: menemukan pola-pola hubungan yang bermakna tentang nilai karakter inklusif-pluralis, dan strategi pembentukan karakter inklusif-pluralis serta memberikan kesimpulan dari data yang telah disajikan berdasarkan pada focus penelitian; dan 3) penarikan kesimpulan/verifikasi.

\section{PEMBAHASAN}

\section{Pendidikan Islam Multikultural}

Pendidikan Islam multikultural pada hakikatnya adalah pendidikan yang menempatkan multikulturalisme sebagai salah satu visi pendidikan dengan karakter utama yang bersifat inklusif, egaliter, dan humanis namun tetap kokoh pada nilai-nilai spiritual dan keyakinan yang berdasarkan 
Alquran dan Al-Hadis. Momentum pendidikan Islam multikultural diyakini dapat menjadi salah satu pondasi bagi terwujudnya kerukunan umat yang beraneka ragam karena realitas kultural bangsa Indonesia yang majemuk. Sementara Baidhawy pendidikan Islam multikultural mengusung pendekatan dialogis untuk menanamkan kesadaran hidup bersama dalam keragaman dan perbedaan. Pendidikan ini dibangun atas spirit kesetaraan dan kesederajatan, saling percaya, saling memahami, dan menghargai persamaan, perbedaan, keunikan dan interdependensi. Oleh karena itu, mengembangkan pendidikan Islam berbasis multikultural menjadi kebutuhan bagi bangsa Indonesia dalam menghadapi tantangan dan tuntutan zaman yang semakin kompeks dan global. ${ }^{1}$ Sebagaimana Muhaimin, mendesak sekali membumikan pendidikan Islam multikultural sebab kesadaran akan pentingnya kemajemukan dan multikulturalisme dapat menjadi perekat baru bagi integrasi bangsa yang sekian lama tercabik-cabik ${ }^{2}$

Secara eksplisit dan implisit eksistensi multikultural dapat ditemukan, bahkan karakter inklusif dapat dijadikan sebagai modal dasar membangun kebersamaan kehidupan kultural seperti toleransi, tolong menolong, moderat dan harmoni. Perilaku-perilaku tersebut merupakan bagian dari ajaran agama, sebagaimana dasar pendidikan islam multikultural yang digali dari Alquran, Diantara teks dan data yang digunakan sebagai landasan multikulturalis dalam Alquran adalah surat Al-Hujarat:13.

Dalam tafsir Al-Jawahir vol VII dijelaskan bahwa kata saling kenal mengenal atau ta'aruf dalam ayat tersebut merupakan indikasi positif dalam suatu masyarakat untuk dapat hidup bersama, saling menghormati dan saling menghargai, menerima perbedaan. Disisi lain, perintah lita'arofu juga dapat menyisakan masalah apabila tidak dibekali dengan solusi terbaik, selanjutnya ayat tersebut diakhiri dengan kemuliaan bagi orang yang bertakwa, sebagai jawaban dan solusi dalam menekan dampak negative dari sebuah dinamika interaksi manusia atau litaarofu. Karena sesungguhnya orang yang paling takwa di antara kamu adalah orang yang bertakwa dari ilmu, ahlak, dan amal-amal mulia, ketakwaan akan mengantarkan kemuliaan seseorang yang bukan diperoleh dengan nasabnya, melainkan dari ketinggian ahlak yang dibingkai ilmu dan amal shaleh. ${ }^{3}$

Nilai merupakan pilihan tindakan manusia yang dapat menjadi pemandu dalam berinteraksi dengan lingkungan sosial agar tujuan hidupnya

${ }^{1}$ Zakiyuddin Baidhawy, Pendidikan Agama Berwawasan Multikultural. (Jakarta: Erlangga, 2005). 67. 2011), 14

2 Muhaimin, Nuansa Baru Pendidikan Islam. (Jakarta: PT Grafindo Persada,

${ }^{3}$ Thantawi Jauhari. Al-Jawahir fi Tafsiri al-Qur'ani al-Karim. (Dar al-Kutubal Ilmiyyah Beirut Lebanon, 2004), 163. 
sesuai dengan hakikat penciptaannya di dunia. Secara aksiologi nilai sebagai panduan hidup manusia, tujuan hidup, pilihan normatif tindakan manusia, dan sebagai hakikat semua pengetahuan. ${ }^{4}$ Sedangkan Muhaimin ${ }^{5}$ mendefinisikan nilai sebagai suatu keyakinan dan kepercayaan yang menjadi dasar bagi seseorang atau sekelompok orang untuk memilih bertindak.

\section{Proses Pembelajaran Pendidikan Islam Multikultural}

Belajar merupakan proses perubahan tingkah laku, sehingga proses pembelajaran juga memiliki peran penting terhadap terjadinya perubahan tingkah laku pada diri seseorang. Proses pembelajaran terdiri dari beberapa komponen yang satu dengan lainnya saling berinteraksi dan berinterelasi, yaitu tujuan, materi pelajaran, metode atau strategi pembelajaran, media, dan evaluasi.Adapun proses pembelajaran dalam kegiatan keagamaan merujuk kepada pedoman majelis taklim yang diterbitkan oleh Kementrian Agama tahun 2012, proses pelaksanaan KBM lembaga pendidikan nonformal, setidaknya ada empat langkah yang dilakukan, yaitu: pengelolahan, kegiatan pembukaan, kegiatan inti, .dan kegiatan penutup.

Dalam pembelajaran pendidikan multikultural di lembaga pendidikan keagamaan, perilaku yang dicontohkan oleh para pemimpin pendidikan memiliki nilai yang sangat penting untuk ditanamkan sejak dini, karena cenderung lebih mengedepankan modelling force sebagai sarana yang paling tepat untuk menanamkan nilai-nilai multikultural. Sebagaimana Stone menyatakan kekuatan teaching force meliputi tiga unsur,pertama kekuatan peniruan, pemberian contoh yang diberikan oleh si pendidik atau modelling force, kedua kekuatan kondisi yang dibangun atau conditioning force, dan ketiga kekuatan kognisi, proses pembentukan pengetahuan atau cognitifforce. ${ }^{6}$

\section{a) Proses Pembelajaran Pendidikan Agama Islam dengan Pendekatan Tasawuf}

Proses pembelajaran pendidikan Agama Islam dengan pendekatan tasawuf mengadopsi gagasan Al-Ghazali yang banyak berorientasi kepada penekanan batin atau aspek afektif dari pada berorientasi pada pengetahuan indrawi. Pendidikan dipandang sebagai sarana atau media untuk mendekatkan diri taqarrub kepada Allah, dan sebagai jalan untuk

\footnotetext{
${ }^{4}$ Risieri Frondizi, Filsafat Nilai. (Yokyakarta: Pustaka Pelajar, 2011). 16.

${ }^{5}$ Muhaimin, Op.Cit, 148.

${ }^{6}$ E Stone, Reading in educational Psychology. (London: Metheun), 102.
} 
menggapai kebahagiaan di dunia dan akhirat yang merupakan kehidupan abadi. $^{7}$ Tujuan yang dikonsepkan Al-Ghazali tersebut, terlihat dengan jelas bahwa orientasi pendidikannya cenderung sufistik dan bersifat rohaniah. Hal ini mencerminkan sikap zuhud Al-Ghazali terhadap dunia, banyak memikirkan kehidupan akhirat, karena kebahagiaan dan kelezatan yang paling tinggi adalah melihat Allah SWT atau ru'yatullah, karena kebahagiaan as saadah itu sesuai dengan watak dan tabiat, watak sesuatu itu sesuai dengan watak ciptaannya. ${ }^{8}$

Dari pendapat tersebut disimpulkan bahwa pendidikan Al-Ghazali bercorak tasawuf dengan mengamalkan ajaran yang bertujuan membentuk ahlak mulia serta memperoleh hubungan langsung dan disadari dengan Tuhannya. Adapun konsep tasawuf Al-Ghazali identik dengan penyucian jiwa dan mendasarkan konsepnya kepada jalur resmi pemikiran sunni atau tasawuf ahlaki melalui penerapan akidah, syariah dan hakikat sebagai satu kesatuan utuh. Oleh karena orang yang menjalani proses pensucian jiwa akan mendapatkan jiwanya bersih dari segala kejahatan dan noda, yang diakibatkan oleh ahlak-ahlak tercela. Proses ini dilakukan melalui riyadah dan mujahadah, karena jiwa yang sehat menjadi sumber ahlak terpuji, karena dengan bebasnya manusia dari sifat tercela dan memenuhinya dengan ahlak terpuji, manusia akan memperoleh kemuliaan dan kesehatan mental karena terbebas dari kotoran. ${ }^{9}$

\section{b) Proses pembelajaran Agama Berwawasan Multikultural}

Baidhawy berpendapat pendidikan agama berwawasan multikultural mengusung pendekatan dialogis untuk menanamkan kesadaran hidup bersama dalam keragaman dan perbedaan yang dibangun atas spirit relasi kesetaraan dan kesederajatan. Berkaitan dengan proses pembelajaran multikultural pada pendidikan agama berwawasan multikultural terdapat beberapa karakteristik utama yang bisa didekati, yaitu: pertama belajar hidup dalam perbedaan, kedua membangun saling percaya atau mutual trust, ketiga memelihara saling pengertian atau mutual understanding, keempat menjunjung sikap saling menghargai atau mutual respect, kelima terbuka dalam berfikir, keenam apresiasi dan interdependensi, dan ketujuh resolusi konflik dan rekonsiliasi nirkekerasan. ${ }^{10}$ 1987), 124.

${ }^{7}$ Muhammad Bin Ahmad Al Ghazali, Ihya'ulum al Din. (Beirut: Dar al Kutub,

\footnotetext{
${ }^{8}$ Ibid, 130.

${ }^{9} \mathrm{Ibid}, 48$.

${ }^{10}$ Baidhawy, Op.Cit, 75.
} 
PENDIDIKAN AGAMA ISLAM MULTIKULTURAL BERBASIS TASAWUF

(Kajian fenomenologis pada Senenan dan Selosoan di Pondok Pesantren Ngalah)

(Uswatun Chasanah)

\section{Model Pendidikan Agama Islam Multikultural Berbasis Tasawuf}

Sebagaimana ditegaskan Rasulullah SAW "Sesungguhnya tiadalah aku diutus kecuali untuk menyempurnakan akhlak yang mulia",beliau merupakan sosok yang patut diteladani bagi umatnya dalam berbagai segi kehidupan, baik sosial, politik, ekonomi, dan pendidikannya.Jika berkaca kepada sejarah kehidupan Nabi SAW dengan sahabat serta pengikutpengikutnya diatas menunjukkan bahwa apa yang dilakukan sebagai kesalehan individualnya dalam beribadah kepada Allah SWT menjadi kekuatan internal yang membawa kepada kesalehan sosial dalam kehidupan sehari-hari. Karena keluhuran budi pekerti yang dibangun dari peri kehidupan kerohanian yang mereka jalani, benar-benar berasal dari ajaran esoteric dalam Islam yang telah dipraktikkan sampai turun temurun. Dengan demikian tidak boleh tidak perilakunya selalu menjadi pelajaran bagi umatnya dulu, kini dan yang akan datang dalam berbagai bidang kehidupan termasuk dalam kesehariannya yang lekat dengan pengamalan keagamaan yang meliputi ritual dan sosial. Oleh karenanya meneladani kehidupan Rasulullah SAW berarti melakukan pendekatan tasawuf, karena benih tasawuf telah ditanamkan beliau sampai turun temurun, disertai pengamalan agama baik mengangkut aspek ibadah dan muamalah. Sebagaimana pendapat Ibn-Athaillah ${ }^{11}$ yang menegaskan bahwa: Baiknya amal adalah hasil dari baiknya budi dan hati, adapun baiknya budi dan hati muncul dari kesungguhan atas apa yang diperintahkan kepadanya.

Pendidikan agama Islam dengan pendekatan tasawuf menjadi bagian dari pengembangan seluruh mata pelajaran pendidikan agama Islam, meliputi mata pelajaran Alquran-hadis, aqidah-ahlak, dan fikih sebagai materi pendidikan agama Islam yang lebih prosedural dan bersifat tehnis. Oleh karena tasawuf digali dari pemahaman terhadap Alquran dan Alhadis secara tekstual dan kontekstual, pengamalan ajaran Islam yang komprehensif, sesuai syariat yang berfungsi meningkatkan keimanan, menguatkan akidah dan berbuah ketakwaan, dan berimplikasi kepada akhlakul karimah.

Orientasi pendidikan yang cenderung sufistik berarti pendidikan bagi kecerdasan emosi dan spiritual atau ESQ, lebih banyak bersifat rohaniah dikenal dengan praktik tarekat. Secara praktis tarekat dipahami sebagai sebuah pengalaman keagamaan yang bersifat esoterik atau dihayati yang dilakukan oleh seorang muslim dengan senantiasa memperhatikan kualitas ibadah ritual dan muamalah sosialnya secara seimbang terhadap

\footnotetext{
${ }^{11}$ Ibnu Athaillah Al-Sakandari, Sarh al-Hikam. (Jeddah: al-Harmain, tt). 40.
} 
lingkungannya dalam harmoni, kesatuan, keseimbangan total dengan totalitas alam. ${ }^{12}$ Demikian ini senada dengan pendapat Mc Neil yang menawarkan model pendekatan humanistik melalui konsep transendensi religius yangmelibatkan mode kesadaran intuitif dengan bentuk meditasi. Pendekatan ini berusaha memberi setiap peserta didik pengalaman yang secara intrinsik bermanfaat bagi kebebasan dan pengembangan pribadi peserta didiknya dengan meningkatkan kesadaran diri. Melalui upaya mengubah keadaan kesadaran, kontrol sukarela dari keadaan dalam dan pertumbuhan melampaui ego. Dari sisi peran guru, kurikulum humanis dituntut adanya kontak hubungan emosional dengan siswanya, karena secara tidak langsung, pengendalian internal akan meningkatkan kualitas sumber daya manusia.

Dari uraian diatas dapat disimpulkan bahwa pendidikan agama dengan pendekatan tasawuf merupakan upaya meneladani kehidupan Nabi SAW, sahabat serta pengikut dibawahnya yang sangat memperhatikan dalam aspek peribadatan sebagai upaya melaksanakan perintah Allah dengan sungguh-sungguh. Meski dengan kesederhanaannya mampu membentuk muslim yang senantiasa mengamalkan ajaran agama secara komprehensif, pendekatan tersebut tidak terlepas dari dasar, tujuan, metode, materi, kurikulum, pendidik, peserta didik, dan lembaga yang berhubungan pengan pelaksanaan pendidikan Islam di masyarakat.

Model pendidikan islam multicultural dengan pendekatan tasawuf tersebut sesuai dengan teori tafsir bahwa hakikat pendidikan Islam adalah pendidikan keimanan sebagai core nya, yakni menanamkan keimanan dalam hati yangakan mengantarkan manusia kepada ketakwaan. Iman tidak berada di badan atau jasmani, tidak pula dipikiran atau di akal, iman berada di hati karena inti sari manusia adalah hati yang berfungsi sebagai pusat kendali manusia. Oleh karena itu menjaga kondisi hati agar senantiasa ingat atau zikir kepada Allah diperintahkan dalam surat Ali Imran:190-192 sebagai berikut: orang-orang yang mengingat Allah sambil berdiri atau duduk atau dalam keadaan berbaring dan mereka memikirkan tentang penciptaan langit dan bumi (seraya berkata):"Ya Tuhan kami, tiadalahEngkau menciptakan ini dengan sia-sia, Maha Suci Engkau, maka peliharalah kami dari siksa neraka.

Dengan mengingat Allah dalam segala kondisi dimaksudkan agar keimanan dan ketakwaan senantiasa dan terus meningkat, karena keimanan dan ketakwaan selanjutnya mempengaruhi sikap, pandangan hidup serta tujuan yang hendak dicapai. Agar tujuan pendidikan dapat tercapai, maka

${ }^{12}$ Amin Syukur, Zuhud di Abad Modern. (Yokyakarta: Pustaka Pelajar. 2004), 45. 
harus dilakukan berbagai upaya untuk mewujudkannya, diantaranya melalui pengamalan tasawuf dan tarekat, karena keduanya berusaha untuk mengamalkan ajaran agama melalui berbagai amalan ibadah ritual sebagai upaya agar ingatan kepada Allah semakin meningkat dan selanjutnya mampu mewarnai kehidupan sehari-hari.

Dari uraian tersebut, secara ideal pendidikan islam harus mampu mencetak manusia secara unggul serta sempurna, yang mengarah pada dua dimensi, jasmani dan rohani, sebagai Abdallah dan sebagai khalifah fil ardl. Untuk mewujudkan hal itu, maka kurikulum pendidikan islam harus memuat beberapa unsur, yaitu ketauhitan, keagamaan yang meliputi ibadah dan muamalat dan ahlak. Dari ulasan model pendidikan melalui pendekatan tasawuf Ibn Athaillah dan model pendidikan islam yang digagas Tafsir sebagaimana dijelaskan diatas dianggap tepat digunakan sebagai gait untuk membangun sebuah teori model pendidikan agama Islam multikultural dengan pendekatan tasawuf.

\section{Tasawuf dan Tarekat}

Definisi tasawuf sangat beragam baik menurut etimologi maupun terminologi, hal tersebut dapat dimaklumi mengingat tasawuf merupakan ilmu hal yang dirasakan oleh masing-masing pribadi manusia dengan berbeda-beda. Secara terminologis tasawuf memiliki banyak definisi, seperti Hamka $^{13}$ menyatakan, tasawuf adalah ahlak luhur atau ihsan yang merupakan refleksi penghayatan keagamaan esoteric yang mendalam, tetapi tidak dengan serta merta melakukan pengasingan diri atau uzlah. Tasawuf dalam perspektif modern menekankan perlunya keterlibatan diri dalam masyarakat dan menanamkan kembali sikap positif terhadap kehidupan dunia. Sementara dalam pengejawantahan tasawuf, manusia akan senantiasa berusaha mendekatkan diri kepada Allah SWT sedekat mungkin dengan penyucian rohani melalui memperbanyak amalan ibadah dan zikir, karena dengan proses penyucian diri, segala konsentrasinya akan tertuju kepadaNya. Di lain pihak upaya taqarrub tersebut akan menjadi landasan dalam aktifitas kesehariaannya yang akan menjadi kerangka kesatuan antara zikir, fikir dan amal shaleh.

Sedangkan tujuan akhir tasawuf adalah menyempurnakan penghambaan manusia melalui pengamalan islam iman dan ihsan dalam aktifitas vertikal dan horizontal, secara khusus Solihin menggagas tujuan tasawuf adalah mendapatkan kebahagiaan jasmani dan rohani, material maupun spiritual. Kebahagiaan merupakan kesempurnaan hidup manusia,

${ }^{13}$ Hamka. Tasauf, Perkembangan dan Pemurniannya. (Jakarta: Pustaka Panjimas, 1995), 94. 
dan untuk memperoleh kesempurnaan dan kebahagiaan terletak pada kesuciannya, sedangkan kesucian manusia terletak pada unsur rohaninya. ${ }^{14}$

Karena kebahagiaan merupakan buah dari setiap perbuatan yang diperintahkan Tuhan seperti ketaatan dan kerelaan dan menjadi pelita hati, sebaliknya setiap kegelapan akan menyisakan kekelaman hati yang akhirnya bila komposisi kegelapan lebih dominan maka akumulasi dari titik-titik hitam akan menjadi penghalang pandangan mata hati kepada-Nya. Akibatnya manusia tidak bisa menikmati pertemuan dengan Tuhan-Nya, kondisi inilah yang akan menjadi petaka bagi para shufi. Oleh sebab itu kontinyuitas penyucian diri terhadap media persinggahan Tuhan harus selalu dijaga ketat dan memerlukan upaya spiritual seperti melalui zikir. Sebagaimana dalam Alquran surat Ar-Ra'du:28 sebagai berikut: (yaitu) orang-orang yang beriman dan hati mereka menjadi tenteram dengan mengingat Allah. Ingatlah, hanya dengan mengingat Allah-lah hati menjadi tenteram.

Karena halam hati atau qalb sebagai bagian dari rohani manusia seringkali muncul potensi negatif kar.ena dikotori oleh berbagai penyakit, seperti sombong, pamer, mencitai dunia, memprovokasi, membicarakan kejelekan orang, seperti halnya jasmani atau raga manusia, unsur rohani atau jiwa manusia juga memiliki potensi negatif yang terletak pada titik-titik lembut atau disebut lataif seperti nafsu amarah, nafsu lawwamah, nafsu bahimiyah dan nafsu sabuiyah. Jiwa adalah kelembutan atau latifah, bersifat halus atau rohaniah. Sebelum bersatu dengan jasad manusia, latifah ini disebut al ruhdan jiwa adalah ruh yang telah masuk dan bersatu dengan jasad dan menimbulkan potensi kesadaran atau al idrak. Ruh yang telah masuk dan bersatu dengan jasad manusia memiliki lapisan-lapisan kelembutan atau lataif yang masing-masing memiliki potensi positif dan negatif.

Dari uraian tersebut disimpulkan bahwa tasawuf menyempurnakan penghambaan manusia kepada Allah SWT melalui islam, iman dan ihsan. Ihsan sendiri secara bahasa berarti berbuat baik, dan terkait erat dengan pendidikan berbudi luhur atau ahlak mulia. Sebagaimana disabdakan Nabi SAW, bahwa yang paling utama dikalangan kaum beriman ialah yang paling baik ahlaknya, bahkan Rasulullah SAW sendiri secara khusus diutus oleh Allah SWT untuk menyempurnakan ahlak manusia, meneladani beliau berarti menyempurnakan keberagamaan atau keislaman umatnya. ${ }^{15}$ Dapat dipahami pula bahwa ihsan meliputi dua dimensi, ritual dan sosial, hal

${ }^{14}$ Anwar dan Solihin, Ilmu Tasawuf.Cet 5. (Bandung: Pustaka Setia, 2000). 142.

${ }^{15}$ Muhammad Fauqi, Al-Tasawuf Al-Islamy wa Al-ahlaq. Vol 2. (Mesir: Mahfudhah, 1995), 45. 
tersebut sesuai dengan kedudukan dan tugas manusia di ciptakan oleh Allah SWT sebagai hamba yang harus senantiasa beribadah dan menghamba kepadaNya melalui ritual, sekaligus sebagai khalifah di bumi yang harus mampu bekerjasama dengan lingkungan untuk membangun kehidupan dalam interaksi sosial yang baik. Dengan menyeimbangkan keduanya, manusia akan mencapai kesempurnaan dalam kehidupannya. ${ }^{16}$ oleh karenanya menyelami dan mengamalkan tasawuf sebagai upaya mengamalkan ihsan perlu dilakukan, karena tasawuf dipercaya akan menjadi jalan atau transportasi manusia untuk sampai kepada tujuan hakikinya yaitu makrifatullah. Sebagaimana ditegaskan dalam Alhadis tentang islam iman dan ihsan sebagai berikut: diriwayatkan oleh abu darr, beliau berkata: suatu ketika Nabi SAW didatangi oleh seorang laki-laki yang bertanya: apakah iman itu? iman adalah engkau beriman kepada Allah, malaikat, rasul dan hari pembalasan. Apakah islam itu?islam adalah engkau beribadah kepada Allah dan tidak menyekutukannya, mendirikan salat, zakat fitrah, puasa di bulan ramadan. Dan apakah ihsan? Ihsan adalah engkau beribadah kepada Allah seakan-akan engkau melihatnya, jika engkau tidak bisa melihatnya, maka percayalah bahwa Allah melihat engkau.

Merujuk kepada Al-Hadis diatas maka ihsan dapat dimaknai secara syariat dengan berbuat baik, seperti berbuat baik kepada orang tua atau birrul walidain, menolong sesama dan sebagainya, dan secara hakikat yang berarti memperbaiki dan menyempurnakan berbagai bentuk amalan ibadah sebagai upaya untuk mendekatkan diri kepada Allah SWT, sekaligus menjadi jalan seseorang mendapat derajat yang tinggi dan luhur. ${ }^{17}$ Sebagaimana Al-Ghazali mengatakan bahwa ahlak mulia dimiliki seseorang bila orang tersebut selalu merasa dilihat oleh Allah, selalu merasa dilihat oleh Allah inilah iman yang sebenarnya. ${ }^{18}$

Ibadah sendiri terdiri dari dua bagian, pertama ibadah maghdah yaitu ibadah wajib yang terdapat dalam rukun Islam, seperti salat, zakat, dan puasa dan kedua ibadah ghairu maghdah yaitu ibadah yang menyempurnakan dan mengiringi amalan wajib seperti melakukan salat sunat, sedekah. ${ }^{19}$ Sebagaimana dalam ibadah salat lima waktu, salat memiliki dua dimensi, ritual dan sosial, dimensi ritual berarti salat

\footnotetext{
${ }^{16}$ Amin Syukur, Op.Cit, 130.

${ }^{17}$ Muhammad Fauqi, Op.Cit, 44.

${ }^{18}$ Muhammad Bin Ahmad Al Ghazali, Op.Cit, 128.

${ }^{19}$ Muhammad Dhiyauddin Al-Kurdi, Al-Akhlaq Al-Islamiyah wa Al-Shufiyyah.AsSaadah (Kairo Mesir. 1995). 74.
} 
merupakan bagian dari ibadah. Sedangkan dalam dimensi sosial, akan terlihat adanya perubahan sikap dan karakter dari seseorang kearah yang lebih baik. Kondisi tersebut dapat diraih manakala seseorang berusaha menjaga kualitas ibadah sebaik-baiknya.Sebagaimana yang diisyaratkan dalam alquran surat Al-Ankabut:45 berikut ini: bacalah apa yang telah diwahyukan kepadamu, yaitu Al Kitab (Al Qur'an) dan dirikanlah shalat. Sesungguhnya shalat itu mencegah dari (perbuatan-perbuatan) keji dan mungkar.Dan sesungguhnya mengingat Allah (shalat) adalah lebih besar (keutamaannya dari ibadat-ibadat yang lain). Dan Allah mengetahui apa yang kamu kerjakan.

Dari uraian tersebut disimpulkan bahwa, perilaku atau ahlak yang diajarkan melalui agama merupakan langkah tepat, karena pendidikan ahlak berbasis kepada keimanan kepada Tuhan-Nya. Dilain pihak ahlak merupakan bagian bahkan inti dari Islam, hal ini sesuai dengan misi Nabi sebagai penyempurna akhlak sekaligus menunjukkan bahwa pendidikan agama seyogyanya belajar kepada para Nabi sebagai penyampai risalah, maka yang dilakukan mereka ialah pendidikan keimanan dan ahlak yang dilakukan melalui metode internalisasi dengan tehnik peneladanan, pembiasaan dan motivasi ${ }^{20}$ Kesemuanya dilakukan sebagai upaya agar melalui proses tersebut diharapkan agar iman dapat tertanam ke dalam hati dan selanjutnya akan menjadi pondasi dan dasar dalam berbagai aktifitasnya di dunia. Karena itulah pendidikan islam seharusnya mengutamakan pembinaan kalbu atau hati. Sebagaimana dikisahkan dalam Alquran surat Al-Hujarat: 14 sebagai berikut: Orang-orang Arab Badui itu berkata: "Kami telah beriman". Katakanlah: "Kamu belum beriman, tapi katakanlah 'kami telah tunduk', karena iman itu belum masuk ke dalam hatimu. dan jika kamu ta'at kepada Allah dan Rasul-Nya, Dia tidak akan mengurangi sedikitpun pahala amalanmu. sesungguhnya Allah Maha Pengampun lagi Maha Penyayang."

\section{Pendidikan dalam Tasawuf}

Pendidikan dalam tasawuf tidak terlepas dari istilah tarekat, karena tarekat merupakan salah satu upaya mensistematiskan ajaran dan metodemetode tasawuf. Tarekat sekaligus menjadi perwujudan dari konsep tasawuf secara riil dengan sikap dan perbuatan nyata dan pelaksanaan sungguhsungguh melalui beberapa tahapan yang telah ditentukan. Dalam hal ini, tarekat sebagai sekelompok murid mengelilingi seorang guru sufisme terkenal mencari pelatihan melalui metode tertentu dalam

20 Ahmad Tafsir, Filsafat Pendidikan Islami. (Bandung: Remaja Rosda Karya, 2014), 224. 
kebersamaan.Karena dengan metode dan sistematika tertentu, guru shüfi dan berharap konsep-konsep tasawufnya lebih mudah dipraktikkan.

Di antara tarekat muktabarah yang mengalami perkembangan pesat di Indonesia adalah Tarekat Naqsyabandiyah, tarekat ini didirikan oleh Muhammad Bahauddin an-Naqsyabandi al-Uwaisi al-Bukhari (w 1389M) di Turkistan. Dalam menjalankan aktivitas dan penebaran tarekatnya, Bahauddin an Naqsyabandi memiliki khalifah utama yaitu: Ya'qub al Karkhi, Ala'al Din Aththar, Muhamad Parsa dan yang paling menonjol adalah Ubaidillah Ahrar. Penyebaran tarekat ini telah menyentuh seluruh lapisan masyarakat muslim di berbagai wilayah seperti: Asia Tengah, Turki, Suriah, Afganistan dan India. Bahkan di Asia tengah diseluruh sudut kota dan kampung-kampung kecil memiliki zawiyah (padepokan shufi) dan rumah peristirahatan Naqsyabandi sebagai tempat berlangsungnya aktifitas keagamaan yang semarak. Sedangkan tahapan-tahapan tasawuf dalam pandangan para sūfi dalam tasawuf akhlaqi terdapat tiga tahapan yang dilakukan dalam mencapai kedekatan dengan Allah SWT, meliputi: takhalli, tahalli, dan tajalli atau makrifatullah.

Sikap merupakan kecenderungan untuk bereaksi dengan cara tertentu terhadap sesuatu perangsang atau situasi yang akan dihadapi, danmenegaskan sikap sebagai kondisi mental yang kompleks, melibatkan keyakinandan perasaan, serta disposisi untuk bertindak.Uraian tersebut dapat dipahami bahwa, pertamasikap merupakan hasil belajar manusia, dapat tumbuh dan dikembangkan melalui proses belajar, dapat dipelajari sepanjang perkembangan orang yang bersangkutan dalam keterkaitannya dengan obyek tertentu. Kedua sikap selalu berhubungan dengan objek, tidak berdiri sendiri, bisa dengan satu obyek dapat pula berhubungan dengan sederet obyek yang sejenis. Ketiga, sikap memiliki hubungan dengan aspek motivasi dan perasaan atau emosi.

Sikap dapat terbentuk atau berubah melalui empat cara, pertama adopsi dari kejadiandanperistiwa yang berulang-ulang dan terus-menerus, lama kelamaan secara bertahap diserap kedalam diri individu danmempengaruhi terbentuknya suatu sikap. Kedua diferensiasi yakni karena berkembangnya intelegensi, pengalaman, umur atau usia. Ketiga integrasi yakni pembentukan sikap yang terjadi secara bertahap dimulai dengan berbagai pengalaman yang berhubungan dengan satu hal tertentu sehingga akhirnya terbentuk sikap mengenai hal tersebut. Keempat trauma yakni pengalaman yang tiba-tiba mengejutkan dan meninggalkan kesan mendalam pada jiwa yang bersangkutan.

Tingkah laku sebagai bentuk reaksi merupakan wujud dari sikap seseorang yang dipengaruhi oleh perasaan baik positif maupun negatif. Jika 
perasaan yang mempengaruhi berasal dari perasaan ketuhanan atau keagamaan, maka perasaan tersebut akan membawa seseorang berbuat baik, dan menjadi sikap positif. Oleh karena itu, sikap positif dapat dikatakan sebagai bagian dari ahlak dalam Islam, dan ahlak dalam tasawuf dimulai dengan kondisi jiwa atau halu an nafs yang melahirkan aktifitas horizontal sesuai suruhan Allah dan RasulNya yang diorientasikan untuk mendapat ridaNya.Oleh karenanya, pendidikan agama islam melalui pendekatan tasawuf memiliki kesesuaian dalam upaya pembentukan sikap positif, karena halu an nafs adalah sumber energi dalam melahirkan sebuah aktifitas, sedangkan keputusan akhir untuk melakukannya atau tidak, segalanya tergantung kepada alqalb untuk memutuskannya. Demikian sebaliknya, keputusan al qalb yang secara formal menjadi kajian tasawuf sangat membutuhkan halu an nafs sebagai su

mber energi yang melahirkan aktifitas. Seseorang yang mengamalkan tasawuf, akan membawa kepada kebersihan hati jauh larangan Allah SWT. Dengan kebersihan hati,akan mempengaruhi sikap yang diambil, karena pada dasarnya seseorang yang mengamalkan ajaran tasawuf akan cenderung melakukan sesuatu didasari oleh ketaatannya kepada Allah SWT, perasaan ini akan membawa seseorang untuk berbuat baik dan menjadi perasaan yang tertinggi dan terdalam kualitasnya.

Pengembangan sikap positif sebagai refleksi ahlak mulia harus dilakukan secara serius, terprogram dan konsistenmelalui pendidikan agama islam dengan pendekatan tasawuf yang bercorak sufi-amali secara singkat metode sufistik yang terhimpun dalam sebuah rentetan prosedur takhalli, tahalli dan tajalli. Karena tasawuf yang dipraktikkan secara sebenarnyaakan menjadi metode efektif dan impretif menghadapi tantangan zaman, karena kaum sufi akan menghadapi bergejolaknya kehidupan dengan kejernihan hati, obyektif dan ketenangan atau thuma'ninah. Sebab bagi kaum sufistik, ilmu dan amal yang tidak disertai dengan kebersihan hati yang diproses melalui pelatihan sufistik dipandang sebagai sesuatu yang sia-sia belaka. Oleh karenanya tasawuf sangat dibutuhkan sebagai semangat era globalisasi yang gersang dari nilai-nilai spiritualitas, meninggalkan nilai-nilai tasawuf dan terjebak dalam kubangan fitnah dunia.

Pendidikan agama Islam multikultural dengan pendekatan tasawuf dimaknai sebagai upaya untuk membina rohani manusia melalui berbagai tahapan yang pada akhirnya dapat membersihkan dan meningkatkan eksistensi manusia. Karena dimensi rohani manusia dipercaya sebagai inti atau core dari manusia, sehingga perlu mendapat perhatian dan perawatan secara khusus, bahwa hati itu ibarat cermin sementara ilmu pengetahuan adalah refleksi gambar yang ada dalam cermin tersebut. Agar hakikat ilmu 
dapat terlihat jelas, maka cermin haruslah bersih dan mengkilap dengan senantiasa mengingat Allah dan mentaatidan menjauhi laranganNya.

Dalam perspektif tasawuf, esensi berbagai tahapan yang diamalkan pelaku tasawuf semata untuk menggapai ihsan yang dapat menyempurnakan agama seseorang. Jika ajaran islamdimaknai sebagai pengamalan ubudiyah, maka ajaran Islam akan terasa kaku dan kering, sebaliknya jika ajaran Islam dimaknai sebagai pengamalan muamalah saja. maka ajaran Islam akan siasia dalam mengantarkan manusia menuju kebahagian dunia dan akhirat. Karena setiap syariat yang dilakukan tanpa disertai hakikat, maka syariat itu rusak, dan tiap hakikat yang tidak disertai syariat maka hakikat itu batal. ${ }^{21}$

Pengembangan pendidikan Islam multikultural dengan pendekatan tasawuf akan menjadi sumber bagi terbentuknya sikap-sikap yang mengarah kepada tujuan multikulturalisme. Karena menyempurnakan ajaran agama dengan mengimplementasikan konsep iman, islam, dan Ihsan, dan sikap multikultural yang merupakan perilaku menghormati, menghargai eksistensi dan keberadaan komunitas lain dengan segala perbedaan yang melekat padanya, oleh karenanya sikap multikultural merupakan bagian dari konsep ihsan itu sendiri. Menurut Schoun yang dikutip Harahap kesadaran terhadap aspek eksoterik dan esoteric merupakan cara terbaik dalam mencapai titik temu semua perbedaan. Karena diterimanya aspek eksoterik dan esoterik dalam agama akan menanamkan prinsip inklusivisme. ${ }^{22} \mathrm{Hal}$ ini mengindikasikan bahwa pendidikan agama islammultikultural dengan pendekatan tasawuf relevan sebagai upaya mengembangkan sikap multikultural masyarakat, melalui usaha perbaikan dan penyempurnaan kesalihan ritual dan sosial. Walaupun tidak semua tasawuf dan tarekat dikategorikan sebagai muktabar, namun keberadaan tasawuf tarekat muktabar merupakan bagian dari aspek spiritualisme Islam yang menyajikan wajah Islam yang lebih inklusif dan mampu bertahan dan melakukan berbagai adaptasi dan akomodasi bahkan berkembang lebih luas.

\section{Nilai-nilai Pendidikan Agama Islam Multikultural yang diajarkan pada Senenan dan Selosoan dalam Pengembangan Sikap Multikultural Masyarakat}

Nilai merupakan sesuatu yang menyempurnakan manusia sesuai dengan hakikatnya sebagai manusia dan berhubungan erat dengan masalah mendasar yang sangat penting dalam kehidupan manusia. ${ }^{23}$ Nilai merupakan

${ }^{21}$ Ahmad Al-Kumaskhanawi, Jami'u al-Ushul al-Awliya'. (Jeddah: Al-harmain,

$\mathrm{tt)} .32$.

${ }^{22}$ Syahrin Harahap, Teologi Kerukunan. (Jakarta: Prenada Media. 2011). 76.

${ }^{23}$ Risieri Frondizi, Op.Cit, 16. 
pilihan tindakan manusia yang dapat menjadi pemandu dalam berinteraksi dengan lingkungan sosial sehingga tujuan hidupnya sesuai dengan hakikat penciptaannya di dunia. Secara aksiologi nilai berfungsi sebagai panduan hidup manusia, tujuan hidup, pilihan normatif tindakan manusia, dan sebagai hakikat semua pengetahuan.

Berdasarkan eksistensi Kiai Sholeh selaku pendidik pada Seninan dan Selosoan, kurikulum yang diajarkan serta pembiasaan yang dikembangkan didukung oleh peneladanan serta habituasi dari pendidik yang diimplementasikan terus menerus dalam ritual dan sosial yang mencerminkan nilai-nilai yang dapat dijadikan sebagai dasar atau fondasi dalam pengembangan sikap multikultural masyarakat adalah berikut ini: Nilai Pendidikan Agama Islam yang diajarkan pada Senenen dan Selosoan dalam Pengembangan Sikap Multikultural yangdilaksanakan di Pesantren Ngalah dipimpin oleh Kiai Sholeh yang memiliki eksistensi tinggi yang diaktualisasikan secata tekstual dan kontekstual dan menghasilkan Nilainilai Islam multikultural yang komprehensif berjumlah Sebelas nilai, yaitu:keimanan dan ketakwaan, keikhlasan, kedamaian. kesabaran, kesederhanaan, kasih sayang, kebersamaan, kekeluargaan, keseimbangan, empati, dan cinta tanah air.

Dari uraian tersebut disimpulkan bahwa Senenan dan Selosoan telah mengembangan nilai-nilai pendidikan islam multikultural, baik dari jumlah serta kualitasnya. Nilai tersebut bersumber dari kontekstualisasi Kiai Sholeh selaku pendidik yang diimplementasikan dalam proses pembelajaran, keteladanan, maupun interaksi antar sesama jamaah dengan lingkungan. Oleh karena itu untuk menghasilkan nilai yang komprehensif, tidak hanya dapat dilihat dari perilaku dan sikapnya, tetapi juga dihayati, dirasakan dalam hati masing-masing pelakunya. Karena melalui penanaman nilai-nilai tersebut secara kontinyu diharapkan bisa membangun tradisi pendidikan agama yang menghargai keberagaman yang ada di lingkungan sekitar, bukan hanya sekedar menghormati tetapi lebih jauh lagi mampu menerima, menghargai keragaman yang ada disekitarnya dengan penuh kesabaran dan keikhlasan dalam membangun kehidupan damai ditengah-tengah keragaman tersebut dengan tetap berpegang kepada Agama Islam secara kaffah.

\section{Proses Pembelajaran yang Didasarkan pada Nilai-Nilai Pendidikan Agama Islam Pada Senenan dan Selosoan}

Dalam melakukan pengkajian terhadap pembelajaran agama pada Seninan dan Selosoan yang dilaksanakan di Pesantren Ngalah bagi masyarakat dan santri, maka langkah pertama adalah mengidentifikasi proses pembelajaran yang digunakan. Adapun hasil observasi pelaksanaan 
pembelajaran agama pada kegiatan tersebut dapat dilihat berdasarkan deskripsi berikut ini:

\section{a. Tahap pengelolaan}

Tahap pengelolaan dimaksudkan sebagai persiapan dan pengaturan jamaah secara keseluruhan yang meliputi sarana prasarana dan peralatan yang diperlukan dalam KBM. Kegiatan ini dilakukan oleh kordinator lapangan yang telah ditunjuk oleh Kiai Sholeh melalui Pengurus Pesantren dan beberapa orang masyarakat yang turut membantu mempersiapkan sarana dan prasarana yang dibutuhkan dalam KBM. Pengelolaan dimulai dengan:sterilisasi Masjid, halaman Masjid serta menyiapkan speaker yang dipakai dalam jamaah salat sehari-hari, sterilisasi halaman Masjid dari beberapa properti yang biasa diletakkan disana sebagai akses masuk area kegiatan, sterilisasi halaman asrama E dan F dari beberapa sampah yang terlihat berada disekitar tempat sampah yang telah disediakan bagi santri, dan pemasangan terpal sebagai tempat salat diseluruh sudut halaman Masjid dan halaman asrama $\mathrm{E}$ dan $\mathrm{F}$ dengan terpal terbuat dari plastik yang telah dibersihkan dan disucikan terlebih dahulu (O. 02.20-08-2018).

\section{b. Tahap Pembukaan}

Secara tertib jamaah mengisi tempat yang telah disediakan, satu persatu menggelar sajadah dan peralatan salatnya. Jamaah yang datang langsung bersalaman dengan jamaah yang lain sambil mencari tempat sesuai dengan kedatangannya. Rasa persaudaraan yang kental menyelimuti para jamaah yang datang dari berbagai daerah, berbagai komunitas, bahkan berbagai etnis, mereka seakan sudah mengenal jamaah yang lain dan tidak menghiraukan perbedaan di antara mereka (O.01.13-02-2018). Kegiatan pembukaan diawali dengan pepujian yang diperdengarkan setelah adzan salat isya' yang dilantunkan oleh santri dengan beberapa kriteria tertentu, dikumandangkan dengan penuh penghayatan sebagai upaya membangun suasana tenang dan khidmad sebagai upaya membangun suasana sambil menunggu datangnya imam.

\section{c. Kegiataan Inti}

Kegiatan inti pada Seninan dan Selosoan menggunakan dua modus pembelajaran, yaitu pengamalan ibadah ritual yang dipimpin satu-satunya pendidik yaitu Kiai Sholeh yang berkedudukan sebagai imam dalam proses penamaln salat, zikir, dan doa. Adapun kedua pembelajaran dengan aksi social yang terintegrasi dalam tausiah dilakukan dengan melibatkan beberapa orang atau kelomok, diantaranya pembaca salawat, kiai Sholeh sebagai penceramah, dan komunitas litas agama yag melakukan live in di Pesantren Ngalah, serta para jamah seninan dan selosoan. Proses pembelajaran Seninan merupakan pengenalan dan implementasi tasawuf 
melalui praktik TNK, kegiatan tersebut sekaligus sebagai pengembangan yang dilakukan oleh Kiai Sholeh dari kegiatan Selosoan yang dilaksanakan Selasa siang sejak berdirinya Pesantren Ngalah. Kegiatan tersebut merupakan permintaan masyarakat yang tidak dapat mengikuti Selosoan karena sibuk bekerja dan beraktifitas pada siang hari sehingga Seninan dilaksanakan pada Senin malam. Oleh karena itu dapat disimpulkan bahwa kegiatan Seninan dan Selosoan merupakan pengenalan, implementasi, sekaligus pengembangan tasawuf melalui praktik TNK yang dilaksanakan di Pesantren Ngalah

\section{KESIMPULAN}

Dari uraian diatas disimpulkan bahwa pendidikan agama islam multicultural berbasis tasawuf merupakan model pendidikan agama islam multikultural yang diajarkan pada Seninan dan Selosoan yang bertujuan mengembangan sikap multikultural dengan menggunakan dua modus proses pembelajaran melalui pengamalan ibadah ritual berjamaah didukung pengamalan TNK sebagai upaya membina rohani dan menambahkan wawasan multikultual dalam tausiyah sebagai upaya mengembangkan jasmani agar keimanan dan ketakwaan semakin meningkat dan mampu menyeimbangkan antara kesalehan ritual dalam menghamba kepada Allah SWT dan pengembangan sikap multikultural sebagai wujud kesalehan sosial dan menghasilkan nilai-nilai pendidikan Islam multikultural yang komprehensif, bermanfaat bagi kehidupan dunia dan akhirat.

\section{DAFTAR PUSTAKA}

Ahmad Al-Kumaskhanawi, tt. Jami'u al-Ushul al-Awliya'. Jeddah: Alharmain.

Ahmad Tafsir, 2014. Filsafat Pendidikan Islami. Bandung: Remaja Rosda Karya.

Amin Syukur, 2004. Zuhud di Abad Modern. Yokyakarta: Pustaka Pelajar. Anwar dan Solihin, 2000. Ilmu Tasawuf.Cet 5. Bandung: Pustaka Setia.

E Stone,1970. Reading in educational Psychology. London: Metheun

Hamka. 2005. Tasauf, Perkembangan dan Pemurniannya. Jakarta: Pustaka Panjimas.

Ibnu Athaillah Al-Sakandari, tt. Sarh al-Hikam. Jeddah: al-Harmain.

Maslikhah. 2007. Quo Vadis Pendidikan Multikultur. Rekonstruksi sistem pendidikan berbasis kebangsaan. Salatiga: STAIN SALATIGA PRESS.

Muhammad Dhiyauddin, Al-Kurdi, 1995. Al-Akhlaq Al-Islamiyah wa AlShufiyyah.As-Saadah Kairo Mesir. 
Muhammad Fauqi, 1995. Al-Tasawuf Al-Islamy wa Al-ahlaq. Vol 2. Mesir: Mahfudhah

Muhammad Bin Ahmad Al Ghazali, 1987, Ihya'ulum al Din. Beirut: Dar al Kutub.

Muhaimin, 2006. Nuansa Baru Pendidikan Islam. Jakarta: PT Grafindo Persada

Risieri Frondizi, 2011. Filsafat Nilai. Yokyakarta: Pustaka Pelajar.

Syahrin Harahap, 2011, Teologi Kerukunan. Jakarta: Prenada Media.

Thantawi Jauhari. 2004. Al-Jawahir fi Tafsiri al-Qur'ani al-Karim. Beirut Lebanon: Dar al-Kutubal Ilmiyyah.

Zakiyuddin Baidhawy, 2005. Pendidikan Agama Berwawasan Multikultural. Jakarta: Erlangga 